\title{
QUALITY OF LIFE IN PATIENTS WITH SPINAL CORD INJURY
}

Inacia Sátiro Xavier de FRANÇA ${ }^{\mathrm{a}}$, Alexsandro Silva COURA ${ }^{\mathrm{b}}$, Francisco Stélio de SOUSA ${ }^{\mathrm{c}}$, Paulo César de ALMEIDA ${ }^{\mathrm{d}}$, Lorita Marlena Freitag PAGLIUCA ${ }^{\mathrm{e}}$

\section{ABSTRACT}

It was aimed to measure the quality of life of adults with spinal cord injury and identify domains that affect the quality of life of these individuals. Epidemiological study, conducted in 2007-2008 in Health Basic Units of Campina Grande/PB. There were 47 participants. It was used a questionnaire composed by: sociodemographic variables, etiology of injury; validated instrument to measure quality of life containing four domains: Physical Health, Environmental, Social Relationships and Psychological with their respective facets. The data collected were processed using descriptive and statistical analysis. The domains with lowest scores were: Environmental (55.20 points), Physical health (58.59 points). The facets that compromise the domains: mobility (55.3\%), work capacity (55.3\%), Financial resources (80.9\%), Opportunities for acquiring new information and skills (51\%), Participation in and opportunities for recreation/leisure activities (68.1\%) and Sexual activity (34\%). Results express the dissatisfaction of participants with quality of life. Nurses should contribute to rehabilitation and social reinsertion of those people, respecting their limitations, emphasizing the remaining potential and capacity for self-care.

Descriptors: Nursing. Disabled Persons. Quality of Life.

\section{RESUMO}

Objetivou-se medir a qualidade de vida de adultos com lesão medular e identificar os domínios que prejudicam a qualidade de vida desses sujeitos. Estudo epidemiológico, realizado no período 2007-2008, em Unidades Básicas de Saúde de Campina Grande/PB. Participaram 47 sujeitos. Utilizou-se questionário contendo variáveis sociodemográficas, etiologia da lesão; instrumento validado para medir qualidade de vida, contendo quatro domínios: Físico, Ambiental, Relações Sociais e Psicológico, com respectivas facetas. Os dados coletados foram processados por meio de análise descritiva e estatística. Domínios com menores escores: Ambiental (55,20 pontos); Físico (58,59 pontos). Facetas que mais comprometem os domínios: locomoção (55,3\%), trabalho (55,3\%), dinheiro (80,9\%), informações (51\%), lazer (68,1\%); vida sexual (34\%). Os resultados expressam a insatisfação dos investigados com a qualidade de vida. O enfermeiro deve contribuir para a reabilitação e reinclusão social da pessoa com lesão medular, respeitando suas limitações, enfatizando o potencial remanescente e a capacidade para autocuidado.

Descritores: Enfermagem. Pessoas com deficiência. Qualidade de vida.

Título: Qualidade de vida em pacientes com lesão medular.

\footnotetext{
a Nurse. PhD in Nursing - Federal University of Ceara-UFC. Professor of the State University of Paraiba-UEPB. Professor of the Master in Public Health-UEPB and in the associate Master in Nursing at University of Pernambuco-UPE/UEPB. Productivity Research Scholarship of the National Council of Scientific and Technological Development-CNPq, Level 2. Campina Grande, Paraiba, Brazil

b Nurse. PhD in Nursing - Federal University of Rio Grande do Norte-UFRN. Scholarship from Coordination of Improvement of Higher Education Personnel-CAPES. Natal, Rio Grande do Norte. Brazil.

c Nurse. PhD in Nursing at UFC. Professor of the UEPB. Professor of the Master in Nursing associated program UPE/UEPB. Campina Grande, Paraiba, Brazil.

d Statistician. PhD in Public Health - University of São Paulo-USP. Adjunct Professor of UECE. Professor of Graduate Nursing PPGENF/ UFC. Fortaleza, Ceara, Brazil.

e Nurse. PhD in Nursing at USP. Professor of UFC. Professor of PPGENF/UFC. Productivity Research Scholarship CNPq, Level 1A. Fortaleza, Ceara, Brazil.
} 


\section{RESUMEN}

Se objetivó medir la calidad de vida de adultos con lesión medular e identificar los dominios que afectan la calidad de vida de estos sujetos. Estudio epidemiológico realizado entre 2007-2008 en Unidades Básicas de Salud, Campina Grande/PB. Participaron 47 sujetos. Se utilizó cuestionario conteniendo variables sociodemográficas, etiología de la lesión; instrumento validado para medir la calidad de vida conteniendo cuatro dominios: Físico, Medio Ambiental, Relaciones Sociales, Psicológicas, con respectivas facetas. Los datos recolectados fueron procesados por medio de análisis descriptivo y estadístico. Los dominios con puntuaciones más bajas: Medio Ambiente (55,20 puntos); Físico (58,59 puntos). Facetas que más comprometen los dominios: locomoción (55,3\%), trabajo (55,3\%), dinero (80,9\%), información (51\%), recreación (68,1\%); vida sexual (34\%). Los resultados expresan insatisfacción de los investigados con la calidad de vida. Enfermeros deben contribuir con rehabilitación, reinserción social de estas personas respetando sus limitaciones, haciendo énfasis al potencial restante y capacidad por el mismo cuidado.

Descriptores: Enfermería. Personas con discapacidad. Calidad de vida.

Título: Calidad de vida en pacientes con lesión medular.

\section{INTRODUCTION}

In Brazil, data on the incidence of spinal cord injury are vague and relatively old, as this condition is often underreported. However, in 2007, the Brazilian health services attended 832,858 clients victims of urban violence ${ }^{(1)}$.

Besides external causes, spinal cord injury can also be caused by tumors, bacterial or viral diseases ${ }^{(2)}$. When this injury is complete an interruption of the passage of nervous stimuli through the spinal with suppression of voluntary movement below the level of injury occurs, implying in sensory, motor and sexual losses, loss of sphincter control of bladder and bowel, and potential complications in the respiratory functions, thermal and circulatory, in addition spasticity and nociceptive processes. When the injury is incomplete, some movement and sensitivity remains in the body segments below the injury due to the function preservation of some nerve roots ${ }^{(3)}$.

Quality of life (QOL) of an individual with spinal cord injury can be assessed according to their health and functionality. QOL is defined as the assessment that a person has in relation to their position in life considering their inclusion in the social, cultural, religious, economic context where they live, from their values, goals and personal concerns ${ }^{(4)}$.

In Brazil, the QOL of people with spinal cord injury is poorly investigated, although this disease is a serious public health problem. In a study conducted in the city of Fortaleza/Ceara, Brazil, the authors found that these people suffer severe impairment of their QOL, especially with regard to social aspects ${ }^{(5)}$. Other Brazilian researchers investigated the QOL of people suffering from spinal cord injury admitted to the rehabilitation program at Sarah Kubistcheck Hospital, Brasilia/ DF, and found that the domains with the worst evaluation scores were related to the environment and physical health; and best scores were related to psychological health and social relationships. For these authors, the limitations and restrictions faced by people with spinal cord injury affect socioeconomic improvement of these individuals, access to health services and can negatively influence their self-esteem and $\mathrm{QOL}^{(6)}$.

As satisfaction with QOL increases the chances of a person with spinal cord injury accept better the prevention and therapeutics of potential health problems ${ }^{(7)}$, in this study was taken as object QOL of adults with spinal cord injury, considering that the individual satisfied with QOL is the one who has physical and psychological health, relates well with their family and their social group, enjoys healthy environment, develop healthy lifestyle, and is independent in activities of daily living and knows how to self-care for themselves.

The lack of an instrument to assess QOL per se, with an international perspective, motivated a group of researchers to prepare the World Health Organization Quality of Life Instrument (WHOQOL-100), a validated instrument to measure quality of life, with transcultural perspective and psychometric characteristics established from a sample derived from 19 study centers ${ }^{(4)}$. This instrument contains 100 questions related to six domains: physical health, psychological, level of independence, social relationships, environment and spirituality/religion/personal beliefs. These domains are divided into 24 facets, each being composed of four questions. Finally, the instrument has 
a $25^{\text {th }}$ facet composed of general questions about QOL. The answers to these questions are given on a Likert scale ${ }^{(4)}$.

For considering WHOQOL-100 a very extensive instrument for application in epidemiological studies, in which the assessment of QOL is just one of the variables investigated, the research team developed the WHOQOL-BREF, an abbreviated version of the WHOQOL-10O ${ }^{(4)}$. Both instruments have been validated.

The WHOQOL-BREF consists of four domains, with respective indicators: Physical Health Domain - pain and discomfort, dependence on medicinal substances and medical aids, energy and fatigue, sleep and rest, activities of daily living, work capacity; Psychological Domain - negative feelings, self-esteem, bodily image and appearance, Social Relationships Domain - personal relationships, sexuality activity and social support; Environmental Domain - freedom, physical safety and security, home environment, financial resources, health services and Participation in and opportunities for recreation/leisure activities, Physical environment (pollution/noise/traffic/climate) and transport. Responses to this instrument are scored following a Likert scale ranging from 1 to 5: (1) very dissatisfied, (2) dissatisfied, (3) neither satisfied nor dissatisfied, (4) satisfied and (5) very satisfied ${ }^{(8)}$.

Thus, starting from the assumption that people with spinal cord injury have difficulties in biological, psychological and emotional character which affect their QOL, it was aimed to measure the QOL of adults with spinal cord injury and identify domains that impair the QOL of these subjects .

The study is justified by the important and costly public health problem that spinal cord injury represents, due to the difficulties experienced by people with this type of injury; by the need to expand nursing knowledge production in this approach, and to contribute to knowledge about the Domains that most affect QOL of people with spinal cord injury, thus strengthening public health policies and the consequent planning of care focused on specific interventions to improve QOL and life habits of these people.

\section{MATERIAL AND METHOD}

This is a epidemiological study, cross-sectional with quantitative approach, conducted from August
2007 to July 2008 in the Basic Family Health Units (BFHU's) of Campina Grande/PB, with all people with SCI registered in these BFHU's.

The prevalence of spinal cord injury in this population was unknown. Therefore, we chose a census sample in which there are no calculation of a "N" sample. So, with the help of Community Health Agents (CHA) of BFHU's, we identified all adults with spinal cord injury in the city, obtaining a total of 47 respondents who were included in the sample, since they met the inclusion criteria: present complete or incomplete spinal cord injury of any etiology, diagnosed by a specialist, be 18 years or older, preserved cognitive function, reside in Campina Grande, be registered in BFHU's, have participated in a rehabilitation program and adhered to the study.

Two instruments were used: a questionnaire developed by the researchers, with closed questions about sociodemographics and etiology of spinal cord injury and the WHOQOL-BREF.

The strategy to approach individuals and collected data were home visits together with CHA's of Family Health Strategy (FHS), responsible for each specific micro-area. Two visits were made: one to explain the research and obtain the signature of the Consent Form from the participant. At this meeting, a second visit was scheduled for the questionnaires application.

The collected data were processed and analyzed in the Statistical Package for the Social Sciences (SPSS) 15.0 for Windows and presented in tables. To reduce the likelihood of typing errors a duplicate data entry was carried out and then the information was compared.

The internal consistency of the WHOQOLBREF was verified by Cronbach's Alpha test, considering variables all questions of the questionnaire and obtainning the values: Total Correlation item, Cronbach's Alpha with deleted item and Total Cronbach's Alpha. We used descriptive statistics to analyze the data, and calculated absolute and simple frequencies, mean, median, standard deviation and amplitude of age. It was found the value of each facet present in four domains: Physical health, Psychological, Social Relationships and Environment, allowing us to obtain the mean response and the knowledge of the facets considered satisfied or unsatisfied.

This manuscript was originated from a final course paperwork ${ }^{(9)}$ linked to the main project 
"Quality of life and health promotion of adults with spinal cord injury" whose study was approved by the Ethics Committee in Research of the State University of Paraiba with protocol No. 0228.0.133.000-07, respecting ethical principles: privacy, confidentiality and autonomy.

\section{RESULTS}

The mean age of participants at the time of injury was 31.70 years $\left( \pm 14.12 ; x_{\min }=13, x_{\max }=61\right)$ and, when the survey was applied 42.95 years $\left( \pm 14.12 ; x_{\min }=19, x_{\max }=73\right)$, with medians of 31 and 44, respectively. As shown in Table 1 , most of the participants are male (91.5\%), it is important to note that $55.3 \%$ suffered a spinal cord injury by fire weapon or fall accident.

The internal consistency of the WHOQOLBREF was assured with the overall result of 0.73 obtained with Cronbach's alpha test, indicating that the scale of this instrument reflected reliably measuring quality of life of participants. In Table 2 are presented the acceptable values of reliability by Cronbach's consistency coefficient for each facet. These values agrees that all instrument items are adequate, since the removal of some item would not significantly change the overall result of the test and therefore the overall reliability of the scale.

\section{Physical Health and Psycological Domains}

The Physical and Psychological domains had scores of 58.59 and 63.82 score, respectively.
In Table 3 are presented the absolute and relative frequencies of the measurement of each facet of these domains.

It was found that the facets that were most affected in physical domain were: mobility (55.3\%), work capacity $(55.3 \%)$ and daily activities $(42.5 \%)$. The facets less affected were: dependence on medicinal substances and medical aids (68.1\%), sleep and rest (48.9\%), pain and discomfort (40.5\%) and energy and fatigue (34.1\%).

In Psychological Domain the facet positive feelings (34.1\%) was the most affected. The facets less affected were: spirituality/Religion/Personal beliefs $(63.8 \%)$, self-esteem (55.3\%) and negative feelings (61.7\%).

\section{Social relationships and Environment Domains}

The Environment and Social relationships domains presented scores of 68.79 and 55.20, respectively. In Table 4 are presented the absolute and relative frequencies of the measurement of each facet of these domains.

With regard to the Social relationships domain, it was showed that the facets were less affected: personal relationships (17\%) and social support (21.3\%). The facet most affected was sexual activity (34\%).

All facets of the Environment domain showed significant percentages of dissatisfaction: financial resources $(80.9 \%)$, opportunities for acquiring new information and skills $(51 \%)$, participation in and opportunities for recreation/leisure activities (68.1\%),

Table 1-Gender and etiology of SCI participants. BFHU's of Campina Grande/PB, Brazil. 2007-2008.

\begin{tabular}{llcc}
\hline \multicolumn{1}{c}{ Variable } & & $\mathbf{N}$ & $\mathbf{\%}$ \\
\hline \multirow{2}{*}{ Gender } & Male & 43 & 91.5 \\
& Female & 4 & 8.5 \\
\hline \multirow{3}{*}{ Etiology } & Fire Weapon & 15 & 31.9 \\
& Fall & 11 & 23.4 \\
& Injury & 8 & 17 \\
& Surgery & 4 & 8,5 \\
& Cancer & 4 & 8,5 \\
& Car accident & 3 & 6,4 \\
& Schistosomiasis & 2 & 4,3 \\
\hline
\end{tabular}

Source: Questionnaire prepared by researchers. 
Table 2 - WHOQOL-BREF questionnaire tested with total Cronbach's alpha, item of total correlation and alpha with deleted item. BFHU's of Campina Grande/PB, Brazil. 2007-2008.

\begin{tabular}{lcc}
\hline \multicolumn{1}{c}{ WHOQOL-BREF } & $\begin{array}{c}\text { Item of total } \\
\text { correlation }\end{array}$ & $\begin{array}{c}\text { Cronbach's alpha } \\
\text { with deleted item }\end{array}$ \\
\hline Pain and disconfort & -0.34 & 0.77 \\
Dependence on medicinal substances and medical aids. & -0.11 & 0.74 \\
Personal relationships & 0.50 & 0.72 \\
Positive feelings & 0.38 & 0.72 \\
Spirituality/Religion/Personal belief & 0.60 & 0.70 \\
Thinking, learning, memory and concentration & 0.26 & 0.73 \\
Freedom, physical safety and security & 0.35 & 0.72 \\
Physical environment (pollution/noise/traffic/climate) & 0.14 & 0.73 \\
Energy and fatigue & 0.32 & 0.72 \\
Bodily image and appearance & 0.41 & 0.71 \\
Financial resources & 0.17 & 0.73 \\
Opportunities for acquiring new information and skills & 0.12 & 0.73 \\
Participation in and opportunities for recreation/leisure activities & 0.44 & 0.71 \\
Mobility & 0.24 & 0.73 \\
Sleep and rest & 0.32 & 0.72 \\
Activities of daily living & 0.51 & 0.71 \\
Work Capacity & 0.44 & 0.71 \\
Self-esteem & 0.66 & 0.70 \\
Home environment & 0.37 & 0.72 \\
Health and social care: accessibility and quality & -0.06 & 0.75 \\
Transport & 0.18 & 0.73 \\
Negative feelings & -0.30 & 0.76 \\
Sexual activity & 0.45 & 0.73 \\
Social support & 0.46 & 0.71 \\
\hline
\end{tabular}

Source: WHOQOL-BREF.

home environment (68.1\%), health and social care: accessibility and quality (44.7\%) and transport (38.3\%).

\section{DISCUSSION}

In Table 1, the basic characterization of spinal cord injury individuals pointed to increased vulnerability of young men, being external violence the prevalent etiology, mainly in urban areas of the metropolis. In a study ${ }^{(5)}$ conducted in the city of Fortaleza/Ceara with 32 people with spinal cord injury, we identified similar results: males, young people and victims of fire weapon. In another study ${ }^{(10)}$ performed in Ontario, Canada with two groups of people with spinal cord injury, it was also found higher prevalence in males. However, the etiology with highest percentage was automobile accidents and fire weapon was in third place.

The mean age at the time of the injury and at the time of data colection found in this study were similar to results found in a research conducted in the United States, which reported mean at the time of injury of 31.8 years and 41.6 years of age at the time of study ${ }^{(11)}$.

In Table 3, the facet pain and discomfort appears with the percentage $(29.7 \%)$ agreeing with 
Table 3 -Distribution of people with spinal cord injury in relation to the measurement of facets of the Physical and Psychological domains. BFHU's of Campina Grande/PB, Brazil. 2007-2008.

\begin{tabular}{|c|c|c|c|c|c|c|c|c|c|c|}
\hline \multirow{2}{*}{ Domain } & \multicolumn{2}{|c|}{ VD $^{*}$} & \multicolumn{2}{|c|}{$\mathbf{D}^{+}$} & \multicolumn{2}{|c|}{ NS-ND ${ }^{\ddagger}$} & \multicolumn{2}{|c|}{$\mathbf{S}^{\S}$} & \multicolumn{2}{|c|}{ VS ||} \\
\hline & $\mathbf{N}$ & $\%$ & $\mathbf{N}$ & $\%$ & $\mathbf{N}$ & $\%$ & $\mathbf{N}$ & $\%$ & $\mathbf{N}$ & $\%$ \\
\hline \multicolumn{11}{|l|}{ Physical Health } \\
\hline Pain and discomfort & 5 & 10.6 & 9 & 19.1 & 14 & 29.8 & 13 & 27.7 & 6 & 12.8 \\
\hline Dependence on medicinal substances and medical aids & 1 & 2.1 & 7 & 14.9 & 7 & 14.9 & 29 & 61.7 & 3 & 6.4 \\
\hline Energy and fatigue & 3 & 6.4 & 10 & 21.3 & 18 & 38.3 & 10 & 21.3 & 6 & 12.8 \\
\hline Mobility & 16 & 34 & 10 & 21.3 & 19 & 40.4 & 1 & 2.1 & 1 & 2.1 \\
\hline Sleep and rest & 7 & 14.9 & 5 & 10.6 & 12 & 25.5 & 14 & 29.8 & 9 & 19.1 \\
\hline Activities of daily living & 9 & 19.1 & 11 & 23.4 & 11 & 23.4 & 13 & 27.7 & 3 & 6.4 \\
\hline Work Capacity & 12 & 25.5 & 14 & 29.8 & 11 & 23.4 & 7 & 14.9 & 3 & 6.4 \\
\hline \multicolumn{11}{|l|}{ Psycological } \\
\hline Positive feelings & 6 & 12.8 & 10 & 21.3 & 19 & 40.4 & 9 & 19.1 & 3 & 6.4 \\
\hline Spirituality/Religion/Personal beliefs & 1 & 2.1 & 7 & 14.9 & 9 & 19.1 & 21 & 44.7 & 9 & 19.1 \\
\hline Thinking, learning, memory and concentration & 1 & 2.1 & 13 & 27.7 & 12 & 25.5 & 17 & 36.2 & 4 & 8.5 \\
\hline Bodily image and appearance & 4 & 8.5 & 8 & 17 & 16 & 34 & 4 & 8.5 & 15 & 31.9 \\
\hline Self-esteem & 2 & 4.3 & 9 & 19.1 & 10 & 21.3 & 14 & 29.8 & 12 & 25.5 \\
\hline Negative feelings & 8 & 17 & 1 & 2.1 & 9 & 19.1 & 23 & 48.9 & 6 & 12.8 \\
\hline
\end{tabular}

${ }^{*} \mathrm{VD}=$ Very dis satisfied; ${ }^{\dagger} \mathrm{D}=$ dissatisfied; ${ }^{+} \mathrm{NS}-\mathrm{ND}=$ Neither satisfied nor dissatisfied; ${ }^{\circledR} \mathrm{S}=$ Satisfied; ${ }^{||}$VS $=$Very satisfied. Source: WHOQOL-BREF.

Table 4 - Distribution of people with spinal cord injury in relation to the measurement of facets of the Environment and Social relationships domains. BFHU's of Campina Grande/PB, Brazil. 2007-2008.

\begin{tabular}{|c|c|c|c|c|c|c|c|c|c|c|}
\hline \multirow{2}{*}{ Domains } & \multicolumn{2}{|c|}{ VD* } & \multicolumn{2}{|c|}{ Dw } & \multicolumn{2}{|c|}{ ND-NSt+ } & \multicolumn{2}{|c|}{ S\$ } & \multicolumn{2}{|c|}{$\mathbf{V S}||$} \\
\hline & $\mathbf{N}$ & $\%$ & $\mathbf{N}$ & $\%$ & $\mathbf{N}$ & $\%$ & $\mathbf{N}$ & $\%$ & $\mathbf{N}$ & $\%$ \\
\hline \multicolumn{11}{|l|}{ Social relationships } \\
\hline Personal relationships & 4 & 8.5 & 4 & 8.5 & 6 & 12.8 & 17 & 36.2 & 16 & 34 \\
\hline Sexual activity & 9 & 19.1 & 7 & 14.9 & 19 & 40.4 & 7 & 14.9 & 5 & 10.6 \\
\hline Social support & 4 & 8.5 & 6 & 12.8 & 3 & 6.4 & 21 & 44.7 & 13 & 27.7 \\
\hline \multicolumn{11}{|l|}{ Environment } \\
\hline Freedom, physical safety and security & 4 & 8.5 & 13 & 27.7 & 18 & 38.3 & 8 & 17 & 4 & 8.5 \\
\hline Physical environment (pollution/noise/traffic/climate) & 4 & 8.5 & 11 & 23.4 & 17 & 36.2 & 13 & 27.7 & 2 & 4.3 \\
\hline Financial resources & 14 & 29.8 & 24 & 51.1 & 9 & 19.1 & - & - & - & - \\
\hline Opportunities for acquiring new information and skills & 5 & 10.6 & 19 & 40.4 & 17 & 36.2 & 3 & 6.4 & 3 & 6.4 \\
\hline $\begin{array}{l}\text { Participation in and opportunities for recreation/ } \\
\text { leisure activities }\end{array}$ & 14 & 29.8 & 18 & 38.3 & 12 & 25.5 & 1 & 2.1 & 2 & 4.3 \\
\hline Home environment & 5 & 10.6 & 5 & 10.6 & 5 & 10.6 & 15 & 31.9 & 17 & 36.2 \\
\hline Health and social care: accessibility and quality & 3 & 6.4 & 14 & 29.8 & 9 & 19.1 & 17 & 36.2 & 4 & 8.5 \\
\hline Transport & 8 & 17 & 14 & 29.8 & 7 & 14.9 & 13 & 27.7 & 5 & 10.6 \\
\hline
\end{tabular}

${ }^{*}$ VD $=$ Very dissatisfied; ${ }^{\dagger} \mathrm{D}=$ dissatisfied; ${ }^{+}$NS-ND $=$Neither satisfied nor dissatisfied; ${ }^{\S} \mathrm{S}=$ Satisfied; $\|$ VS $=$ Very satisfied. Source: WHOQOL-BREF. 
other research on the prevalence of pain in people with spinal cord injury. The pain may appear up to 48 months post-trauma, It can result from their own sequels, the bed position, spasticity, flexion and extension of upper and lower limbs or physical activities, hypersensitivity to touch and use of clothing. Pain affects the ability to perform cognitive, social, recreational, and work activities ${ }^{(12)}$.

The participants' dissatisfaction with mobility corroborates with study showing the lowest mean face $^{(13)}$. For some authors spinal cord injury affect musculoskeletal system that result in sensoryperceptual impairment, intolerance to physical exertion and limitation in the capacity of walking. Mobility is impaired when the urban architecture does not provide secure access as a result of disobedience to the rules and standards addressed to define and regulate the prevention and the safety of all people who live there ${ }^{(14)}$.

In this study, they emphasized the fact that 20 participants $(42.5 \%)$ claimed dissatisfaction with the performance of activities of daily living, exemplified by the disadvantages and limitations that result in the development of dependency and loss of autonomy to dress up, sanitize themselves and feed themselves.

Dissatisfaction with work capacity $(55.3 \%)$ resembles a research carried out under national unemployment of people with disabilities which identified that as a triggering element of dissatisfaction and social rejection ${ }^{(14)}$, although these people have in their favor the Law No. 8.213/91 which recommends that companies meet the $2 \%$ to $5 \%$ of their job positions for rehabilitated beneficiaries. Nevertheless, research conducted in $2007^{(15)}$ pointed out that most people with disabilities are inactive and many live in extreme poverty situation.

In the psychological domain it was identified impairment in the facet positive feelings (34.1\%), bodily image and appearance (25.5\%), self-esteem $(23.4 \%)$ and negative feelings (19.1\%). These facets are related to the representations of the individual with regard to his disability and are related to the meaning given to disability, for him and for his social environment ${ }^{(16)}$.

In Table 4 , the majority $(72.4 \%)$ of participants reported being very satisfied with the Social support, however, the social relationships domain, the facet sexual activity (34\%) showed significant dissatisfaction. It is explained that sexual dysfunc- tion results from damage at $\mathrm{C} 2$ to $\mathrm{C} 5, \mathrm{~T} 2, \mathrm{~T} 3, \mathrm{~T} 5$ to T7, T9, T11, T12, S2 and S4, getting ejaculation more affected than the erection. When injury occurs in medullaris conus and in the nerves that composes cauda equina, are much greater the risks of changes in arousal, erection, emission, ejaculation and even the corresponding psychophysical experience of orgasm $^{(17)}$.

In the environment domain, the facets with the highest percentage of dissatisfaction were: financial resources $(80.9 \%)$, opportunities for acquiring new information and skills (51\%), participation in and opportunities for recreation/leisure activities (68.1\%) and transport (46.8\%). In this context, it is important to note that all these facets are related to independent living and participation within the community.

The analysis of the facet transport (46.8\%) showed to affect participants in relation to the right to come and go, due to lack of adapted urban transport. This result approached to another study in which participants relyed on transport of family, friends, ambulance, taxi or carriage $e^{(18)}$.

The results of this study confirm the authors thought about the need to rearrange public policy and reorganize health services ${ }^{(19)}$, in order to provide care that enable improving the domains and facets that affect the QOL of people with physical disabilities.

\section{Implications of the study for nursing professionals}

The role of the nurse in the rehabilitation and social re-inclusion of people with spinal cord injury may occur through the development of procedures and actions centered on respect for their limitations, emphasizing its remaining potential and ability for self-care, and the development of educational process with the individual affected by spinal cord injury and their families, in order to advance their functional independence, preventing secondary complications, the adaptation of the family and himself/herself to the situation.

Spinal cord injury triggers an emotional response that initially manifests itself through negative feelings. The nurse plays an important role helping the affected person to face existential crisis, demonstrating empathy and understanding for their lived experience, establishing trust and positive attention, listening to their complaints, helping 
to recognize and express their negative feelings, and encouraging them to replace them with positive feelings. It is vital to support these individuals at phases of suffering and in decision-making through discussion of their emotional experiences and recognizing the influence of spirituality on their health status, especially in those cases where expressions of concern, loneliness and impotence arise ${ }^{(20)}$.

This type of care requires the development of a social support network, a fundamental support to the nurse, to the individual and his/her family. This social network is a system composed of several people, among which, family members, friends, colleagues, neighbors and professionals who can help in several ways to improve the QOL of the person assisted stand out.

\section{CONCLUSION}

The results of the study showed that QOL of people affected by spinal cord injury is not satisfactory. The limitations of this injury results in negative impacts on the lives of affected people and the domains of greatest negative influence on QOL are the Physical health and Environment. It was found that the most significant items in the domains affected were mobility, work capacity, financial resources, opportunities for acquiring new information and skills, participation in and opportunities for recreation/leisure activities, sexual activity and positive feelings.

With the confirmation of the internal consistency of the WHOQOL-BREF, the instrument is considered reliable and is a good tool that may be used to quantify the QOL of people with disabilities and other social segments. Nurses can make use of this tool in their routine assistance, since application demands few resources and reduced time.

Despite the WHOQOL-BREF presented itself as a good tool, it is recommended that nurse researchers develop, test and validate an instrument to assess QOL specific to people who have suffered spinal cord injury, incorporating it as a possibility for application in systematic nursing process.

We conclude that although there is the National Policy for the Integration of Disabled Persons to ensure rights in health, education, professional training, work, culture, tourism and leisure, the disabled persons, especially those with spinal cord injury, still struggle to improve QOL.

\section{REFERENCES}

1 Ministério da Saúde (BR). DATASUS: Indicadores e Dados Básicos Brasil 2008. [Internet] Brasília (DF): MS; 2008 [citado 2011 jun 12]. Disponível em: http://www.datasus.gov.br

2 Blanes L, Carmagnani MIS, Ferreira LM. Quality of life and self-esteen of persons with paraplegia living in São Paulo, Brazil. Qual Life Res. 2008; 18(1):15-21.

3 Galvin LR, Godfrey HPD. The impact of coping on emotional adjustment to spinal cord injury (SCI): review of the literature and application of a stress appraisal and coping formulation. Spinal Cord. 2001; 39(12):615-27.

4. Fleck MPA. O instrumento de avaliação de qualidade de vida da Organização Mundial da Saúde (WHOQOL-100): características e perspectivas. Ciênc saúde coletiva [Internet]. 2000 [citado 2011 jun 20]; 5(1):33-8. Disponível em: http://www. scielo.br/scielo.php?script $=$ sci_arttext\&pid $=\mathrm{S} 1413$ $-81232000000100004 \& \operatorname{lng}=\mathrm{en} \& n \mathrm{rm}=$ iso

5 Vall J, Braga AB, Almeida PC. Estudo da qualidade de vida em pessoas com lesão medular traumática. Arq neuropsiquiatr. 2006; 64(2-B):451-5.

6 Nogueira PC, Caliri MHL, Haas VJ. Profile of patients with spinal cord injuries and occurrence of pressure ulcer at a university hospital. Rev latinoam enferm. 2006; 14(3):372-7.

7 Whalley HK. Quality of life after spinal cord injury: a meta-synthesis of qualitative findings. Spinal Cord. 2007; 45(2):124-39.

8 Fleck MPA, Louzada S, Xavier M, Chachamovich E, Vieira G, Santos L, et al. Aplicação da versão em português do instrumento abreviado de avaliação de qualidade de vida "WHOQOL-bref”. Rev saúde pública. 2000; 34(2):178-83.

9 Coura AS. Qualidade de vida de adultos com lesão medular: um estudo com o WHOQOL-bref. [monografia]. Campina Grande: Universidade Estadual da Paraíba; 2009.

10 10.Veigh SA, Hitzig SL, Craven BC. Influence of Sport Participation on Community Integration and Quality of Life: A Comparison Between Sport Participants and Non-Sport Participants With Spinal Cord Injury. J Spinal Cord Med. 2009; 32(2):115-24. 
11 Krause JS, McArdle JJ, Pickelsimer E, Reed KS. A Latent Variable Structural Path Model of Health Behaviors After Spinal Cord Injury. J Spinal Cord Med. 2009; 32(2):162-74.

12 Marcia M, Campo KD. Dor no paciente com lesão medular: uma revisão. Rev bras anestesiol. 2009; 59(3):350-7.

13 Bampi LNS, Ghilhem D, Lima DD. Qualidade de vida em pessoas com lesão medular traumática: um estudo com o WHOQOL-bref. Rev bras epidemiol [Internet]. 2008 [citado 2011 jun 20]; 11(1):67-77. Disponível em: http://www.scielo.br/pdf/rbepid/ v11n1/06.pdf

14 França ISX, Pagliuca LMF, Baptista RS, França EG, Coura AS, Souza JA. Violência simbólica no acesso das pessoas com deficiência às unidades básicas de saúde. Rev bras enferm. 2010; 63(6):964-70.

15 Nery M. Retratos da deficiência no Brasil. Rio de Janeiro: FGV/IBRE/CPS; 2003.
16 Fechio MB, Pacheco KMB, Kaihami HN, Alves VLR. A repercussão da lesão medular na identidade do sujeito. Acta fisiátrica. 2009; 16(1):38-42.

17 Maior IMML. Disfunção sexual. In: Greve JMDA, Casalis MEP, Barros Filho TEP. Diagnóstico e tratamento da lesão da medula espinhal. São Paulo: Roca; 2001.

18 Venturini DA, Decesaro MN, Marcon SS. Conhecendo a história e as condições de vida de indivíduos com lesão medular. Rev gaúch enferm. 2006; 27(2):2 19-29.

19 Girondi JBR, Santos SMA. Deficiência física em idosos e acessibilidade na atenção básica em saúde: revisão integrativa da literatura. Rev gaúch enferm. [Internet]. 2011 Jun [citado 2011 ago 21]; 32(2):378-84. Disponível em: http://www.scielo.br/scielo.php? script=sci_ arttext\&pid=S1983-1447201 1000200023\&lng=pt. http://dx.doi.org/10.1590/S1983-14472011000200023.

20 Amaral MTMP. Encontrar um novo sentido da vida: um estudo explicativo da adaptação após lesão medular. Rev Esc Enferm USP. 2009; 43(3):573-580.

\author{
Author's address / Endereço do autor / \\ Dirección del autor \\ Inacia Sátiro Xavier de França \\ Rua Sérgio Rodrigues de Oliveira, 139, Alto Branco \\ 58401-566, Campina Grande, PB \\ E-mail: inacia.satiro@gmail.com
}

Received: 28.09.2011

Approved: 22.01.2013 